\title{
Pengaruh Kompetensi Profesional Guru Terhadap Minat Belajar Siswa Di MTS Negeri 2 Kota Palangka Raya
}

\author{
O.P. Setiawati, Y.I. Nyalung, Jairi \\ Program Studi Pendidikan Ekonomi \\ Fakultas Keguruan dan Ilmu Pendidikan \\ Universitas Palangka Raya \\ Kampus UPR Tunjung Nyaho Jalan Hendrik, Indonesia \\ (Diterima 12-09-2019; Disetujui 14-11-2019)
}

\begin{abstract}
ABSTRAK
Beberapa permasalahan yang sering muncul dalam dunia pendidikan adalah, banyaknya masyarakat yang berminat menggeluti profesi ini, namun sangat sedikit dari mereka yang benarbenar berkompeten di bidang profesi keguruan, atau dengan kata lain belum memenuhi kriteria kompetensi profesional guru. Guru yang memiliki kompetensi profesional guru adalah guru yang berkualitas, berkompeten, dan guru yang dikehendaki untuk mendatangkan suasana belajar yang menyenangkan serta mampu mempengaruhi proses belajar siswa yang nantinya akan menghasilkan minat belajar siswa. Penelitian ini dilakukan untuk mengetahui pengaruh kompetensi profesinal guru terhadap minat belajar siswa.

Sampel dalam penelitian ini terdiri dari guru dan siswa. Hasil penelitian ini diperoleh persamaan regresi linier $\mathrm{Y}=7,665+0,285 \mathrm{X}$. Dari persamaan tersebut diketahui nilai regresi variabel $\mathrm{X}$ sebesar 0,285 yang berarti bahwa setiap penambahan 1 nilai kompetensi profesional guru, maka nilai minat belajar siswa bertambah sebesar 0,285. Nilai signifikan $=0,003<0,05$. Karenanilai signifikan lebih kecil dari nilai probabilitas 0,05 maka dari itu dapat diartikan bahwa terdapat pengaruh yang signifikan kompetensi profesional guru terhadap minat belajar siswa di MTsN 2 Kota Palangka Raya.Berdasarkan hasil perhitungan koefisien determinasi R Square $\left(\mathrm{R}^{2}\right)$ diperoleh nilai $\mathrm{R}^{2}=0,588$. Artinya adalah pengaruh kompetensi profesional guru terhadap minat belajar siswa sebesar 58,8\% dengan kategori sedang. Sedangkan sisanya 41,2\% dipengaruhi oleh variabel - variabel lain diluar model regresi dalam penelitian ini.
\end{abstract}

Kata Kunci : Kompetensi Profesional Guru , Minat Belajar Siswa

\section{PENDAHULUAN}

Belajar adalah proses interkasi terhadap semua situasi yang ada disekitar individu. Belajar dapat dipandang sebagai proses yang diarahkan kepada tujuan dan proses berbuat melalui berbagai pengalaman. Kegiatan pembelajaran dilakukan oleh dua orang pelaku , yaitu guru dan siswa. Guru adalah salah satu komponen manusiawi dalam proses belajar mengajar, yang ikut berperan dalam usaha pembentukan sumber daya manusia yang potensial dibidang pembangunan. Oleh karena itu, guru yang merupakan salah satu unsur dibidang kependidikan harus berperan secara aktif dan menempatkan kedudukannya sebagai tenaga profesional, sesuai dengan tuntutan masyarakat yang semakin berkembang.

Menjadi seorang guru tidaklah semudah yang dibayangkan, karena di samping harus menguasai materi ajar yang akan diberikan kepada peserta didik, secara akademis guru tersebut juga harus menempuh jenjang pendidikan keguruan. Profesi guru memiliki syarat-syarat tersendiri yang harus dipenuhi oleh seseorang yang akan menggeluti profesi ini. Beberapa permasalahan 
yang sering muncul dalam dunia pendidikan adalah, banyaknya masyarakat yang berminat menggeluti profesi ini, namun sangat sedikit dari mereka yang benar-benar berkompeten di bidang profesi keguruan, atau dengan kata lain belum memenuhi kriteria kompetensi profesional guru.

Guru yang memiliki kompetensi profesional guru harus memiliki kemampuan penguasaan materi pembelajaran secara luas dan mendalam. Artinya guru harus memiliki pengetahuan yang luas berkenaan dengan bidang studi yang akan diajarkan serta penguasaan didaktik metodik dalam arti memiliki pengetahuan konsep teoritis, maupun model, strategi, dan metode yang tepat serta mampu menerapkan dalam kegiatan pembelajaran. Guru yang memiliki kompetensi profesional guru akan tercermin dalam pelaksanaan pengabdian tugas-tugas yang ditandai dengan keahlian baik dalam materi maupun metode. Selain itu juga ditunjukkan melalui tanggung jawabnya dalam melaksanakan seluruh pengabdiaannya. Guru yang memiliki kompetensi profesional guru mempunyai tanggung jawab pribadi, sosial, intelektual, moral dan spiritual. Guru yang memiliki kompetensi profesional guru merupakan faktor penentu berkualitas.

Di dalam dunia pendidikan, guru adalah seorang pendidik, pembimbing dan pelatih pesrta didik untuk menciptakan kondisi dan suasana belajar yang kondusif ,yaitu suasana belajar yang menyenangkan, menarik, memberi rasa aman ,memberikan ruang kepada siswa untuk berfikir aktif , kreatif, dan inovatif. Selain guru, siswa juga menjadi komponen yang berpengaruh dalam keberhasilan proses belajar mengajar. Saat ini tugas guru di kelas tidak hanya sebagai sumber belajar saja, tetapi juga sebagai fasilitator, sebagai pengelola, demonstrator, pembimbing, dan sebagai motivator siswanya agar terus semangat dalam belajar. Faktor lain yang berasal dari dalam diri siswa yang dapat menentukan berhasil atau tidaknya proses belajar mengajar adalah minat.

Dari hasil observasi awal berupa pengamatan di lapangan yang penulis lakukan saat pelaksanaan PPL II di MTs N 2 Kota Palangka Raya, penulis memperhatihan proses guru dalam kegiatan pembelajaran dari sebelum mengajar, saat mengajar dan setelah mengajar. Pada saat sebelum mengajar ada beberapa guru yang membuat persiapan seperti menyiapkan media pembelajaran dan ada juga guru yang tidak menyiapkan media pembelajaran. Proses belajar mengajar dikelas yang diajar oleh guru yang menyiapkan media pembelajaran, siswanya cenderung lebih menyukai dan bersemangat mengikuti proses belajar dan siswa lebih aktif.

Sedangkan proses belajar mengajar dikelas yang diajar oleh guru yang tidak membuat media pembelajaran, siswanya kurang bersemangat mengikuti pelajaran dan keaktifan siswa dalam mengikuti pelajaran cenderung kurang, siswa hanya diam mendengar dan mencatat apa yang diajarkan oleh gurunya, suasana kelas tampak sangat srius dan kaku yang cenderung membuat siswa bosan belajar. Guru yang melakukan persiapan sebelum mengajarpun dalam proses pembelajarannya menggunakan metode pembelajaran yang beragam dan tidak monoton pada satu metode belajar saja, sedangkan guru yang tidak melakukan persiapan cenderung hanya menggunakan metode ceramah pada saat proses belajar mengajar.

Ada guru yang memliki latar belakang bukan dari jurusan pendidikan melaikan jurusan ekonomi dan guru tersebut tidak begitu paham mengenai RPP ( Rencana Pelaksanaan Pembelajaran ) dan dalam pelaksanaan pembelajaran dikelaspun guru tersebut tidak dapat membuat suasana kelas yang menyenangkan dimana siswa terlihat diam dan bosan. Berbeda dengan guru yang memiliki latar belakan di jurusan pendidikan dimana guru tersebut dalam pelaksanaan pembelajaran dapat membuat susana kelas menjadi lebih nyaman dan siswa terlihat lebih aktif siswa tidak mudah bosan karena guru tersebut banyak melakukan interaksi dengan siswa.

Dari apa yang dipaparkan tersebut, penulis sangat tertarik untuk mengkaji lebih lanjut tentang kompetensi profesional guru kaitannya dengan minat belajar siswa, dalam sebuah skripsi yang berjudul Pengaruh Kompetensi Profesional Guru Terhadap Minat Belajar Siswa Di Mts Negeri 2 Kota Palangka Raya. 


\section{METODE PENELITIAN}

Unit analisis dalam penelitian ini adalah siswa MTs Negeri 2 Kota Palangka Raya. Populasi dalam penelitian ini adalah seluruh guru dan siswa MTs Negeri 2 Kota Palangka Raya yang dimana guru berjumlah 46 dan siswa berjumlah 952. Seluruh populasi dalam penelitian ini baik guru maupun siswa bersifat homogen. Karena populasi guru bersifat homogen, jadi pengambilan sampel guru dalam penelitian ini menggunakan teknik Simple Random Sampling. Jadi, semua unsur dari populasi mempunyai kesempatan yang sama untuk dipilih sebagai anggota sampel. Jumlah sampel guru dalam penelitian ini sebanyak 41 responden. Sedangkan sampel siswa dalam penelitian ini adalah siswa kelas 7 MTs Negeri 2 Kota Palangka Raya. Karena populasi siswa pada penelitian ini bersifat homogen dan maka sampel diambil secara random sebanyak 100 siswa. Teknik yang digunakan penulis untuk mengumpulkan data yaitu observasi dan angket.

Dalam penelitian ini instrumen yang digunakan berupa kuesioner, yang terdiri atas pernyataan yang dirancang untuk mengukur variabel kompetensi profesional guru ( $\mathrm{X}$ ) dan variabel minat belajar ( $\mathrm{Y}$ ). Angket ini menggunakan skala Likert. Menurut Sugiyono (2013:134) Skala Likert digunakan untuk mengukur sikap, pendapat, dan presepsi seseorang atau sekelompok orang tentang fenomena sosial. Masing - masing item dibuat dengan skala 1-5 kategori jawaban, setiap jawaban diberi skor atau bobot yaitu banyaknya 1 sampai 5 .

Uji validitas digunakan untuk mengukur sah atau valid tidaknya suatu kuesioner. Ghozali (2006:78) menyatakan "suatu kuesioner dikatakan valid jika pertanyaan pada kuesioner mampu untuk mengungkapkan suatu yang diukur oleh kuesioner tersebut". Tujuan dari pengujian validitas ini adalah untuk mengetahui kelayakan kuesioner untuk dijadikan instrumen penelitian. Reliabilitas menunjukan pada suatu pengertian bahwa suatu instrumen cukup dapat dipercaya untuk digunakan sebagai alat pengumpul data. Untuk menghitung uji reliabilitas pada penelitian ini dilakukan dengan program SPSS dengan teknik Alpha Cronbach.

Data penelitian ini akan dianalisis secara simultan dengan menggunakan analisis regeresi sederhana. Pengujian secara simultan ini untuk meneliti pengaruh variabel independen secara keseluruhan terhadap variabel dependen. Sebelum dilakukan uji hipotesis dilakukan uji analisis dengan uji normalitas data menggunakan Kolmogorof Smirnov, dan uji linieritas regresi. Uji normalitas dimaksudkan untuk mengetahui apakah data variabel berdistribusi normal atau tidak. Pengujian normalitas ini menggunakan Kolmogorof Smirnov dengan bantuan komputer program SPSS 24 For Windows. Uji linieritas dilakukankan untuk mengetahui apakah variabel bebas memiliki lineritas terhadap variabel terikat. Uji ini biasanya digunakan sebagai prasyarat dalam analisis korelasi atau regresi. Pengujian ini dilakukan dengan menggunakan Test For Linearity pada taraf signifikan 0,05 . Kedua variabel dikatakan mempunyai hubungan linier apabila nilai signifikansi > 0,05. Uji linieritas dilakuakn dengan bantuan komputer program SPSS 24 For Windows.

Pengujian hipotesis dilakukan dengan metode regresi linier sederhana . Regresi linier sederhana digunakan untuk menguji sejauh mana hubungan sebab akibat antara variabel independen $(\mathrm{X})$ terhadap variabel dependen $(\mathrm{Y})$. Uji hipotesis dalam penelitian ini menggunakan metode regresi dengan bantuan komputer program SPSS 24 For Windows. Selanjutnya untuk mengetahui seberapa besar pengaruh kompetensi profesional guru $(\mathrm{X})$ terhadap minat belajar $(\mathrm{Y})$, maka dilakuakan alanalisis koefisien determinasi $\mathrm{R}$ Square $\left(\mathrm{R}^{2}\right)$. Analisis koefisien determinasi $\mathrm{R}$ Square $\left(\mathrm{R}^{2}\right)$ dalam penelitian ini menggunakan bantuan komputer program SPSS 24 For Windows. Hasil analisis yang diperoleh akan dibandingkan dengan kriteria koefisien. Kriteria koefisien dapatdilihat pada tabel dibawah ini. 


\section{HASIL DAN PEMBAHASAN}

Jumlah seluruh siswa di MTsN 2 Kota Palangka Raya berjumlah 952 dan guru berjumlah 46. Peneliti disini mengambil sampel sebanya $10 \%$ dari jumlah siswa yaitu sebanyak 100 siswa dari 25 kelas dimana setiap kelas diwakili 4 orang responden. Untuk sampel guru peniliti mengambil 41 guru. Berikut ini akan disajikan karakteristik responden berdasarkan jenis kelamin.

Tabel 1. Karakteristik Responden Guru

\begin{tabular}{lcc}
\hline Jenis Kelamin & Frekuensi & Presentase \\
\hline Laki - laki & 14 & $35 \%$ \\
Perempuan & 27 & $65 \%$ \\
\hline Jumlah & 41 & $100 \%$ \\
\hline
\end{tabular}

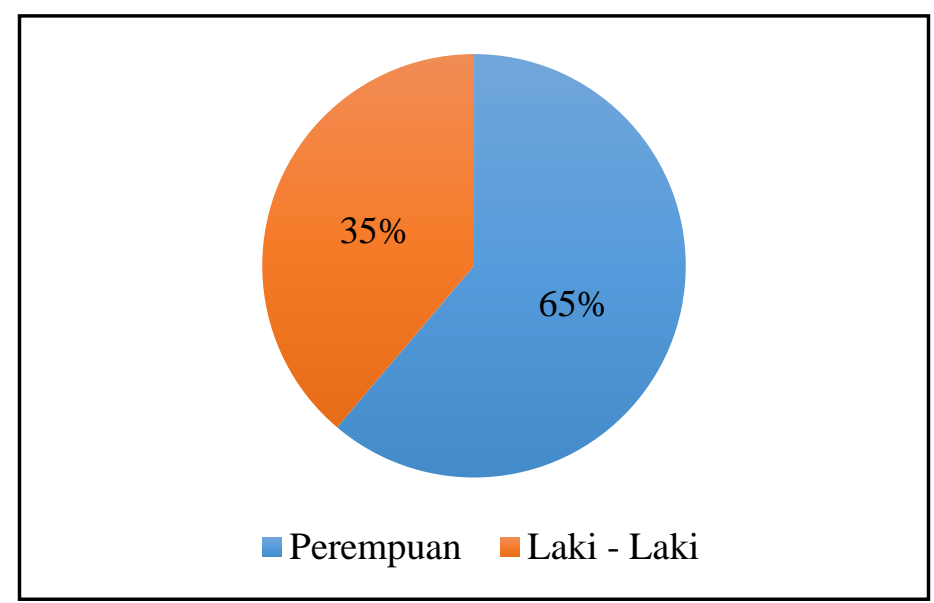

Gambar 1. Diagram Karakteristik Responden Guru

Tabel 2. Karakteristik Responden Siswa

\begin{tabular}{lcc}
\hline Jenis Kelamin & Frekuensi & Presentase \\
\hline Laki - laki & 23 & $23 \%$ \\
Perempuan & 77 & $77 \%$ \\
\hline Jumlah & 100 & $100 \%$ \\
\hline
\end{tabular}

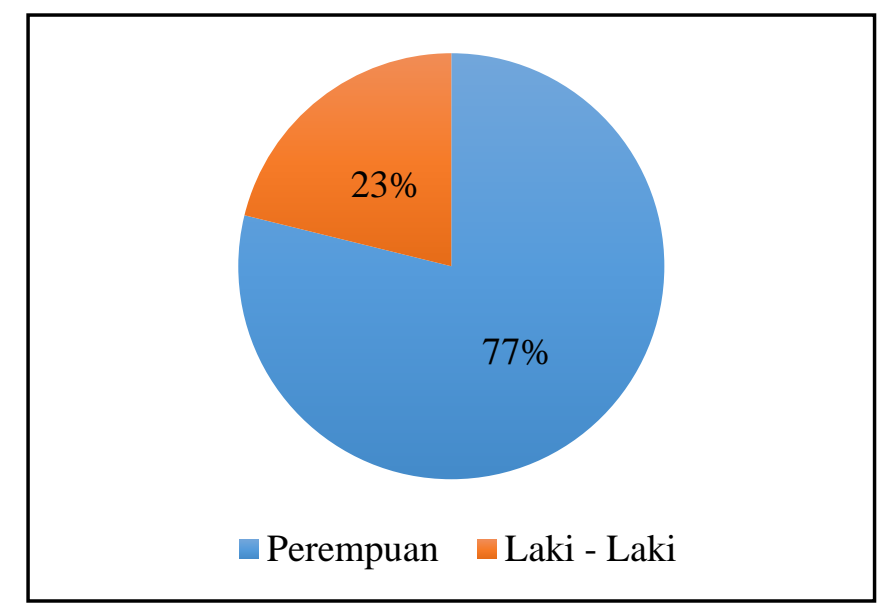

Gambar 2. Diagram Karakteristik Responden Siswa 
Untuk mengetahui nilai kompetensi profesional guru terdapat 19 butir pertanyaan yang disediakan dengan 5 alternatif jawaban. Disini penulis akan memaparkan data hasil jawaban angket yang penulis sebarkan pada guru di MTsN 2 Kota Palangka Raya yang berjumlah 41 orang guru. Data yang terkumpul mengenai kompetensi profesional guru dengan instrumen sebanyak 19 item pertanyaan dari 41 responden, diketahui bahwa skor rata - rata (mean) adalah 85,7 dengan rentang standar deviasi sebesar 4,5. Rentang skor (range) adalah 22 dengan skor minimum adalah 70 dan skor maksimum adalah 92. Nilai tengah (median) adalah 86 serta nilai yang sering muncul (mode) adalah 86 .

Tabel 3. Distribusi Frekuensi Variabel Kompetensi Profesional Guru

\begin{tabular}{cllcr}
\hline \multirow{2}{*}{ No } & Interval Skor & Kriteria & Frekuensi \\
\cline { 3 - 5 } 1 & $70-74$ & Sangat Kurang & 1 & $\%$ \\
2 & $75-80$ & Kurang & 3 & $7 \%$ \\
3 & $81-85$ & Cukup & 11 & $27 \%$ \\
4 & $86-90$ & Baik & 21 & $51 \%$ \\
5 & $91-95$ & Sangat Baik & 5 & $12 \%$ \\
\hline
\end{tabular}

Berdasarkan tabel diatas dapat diketahui dari 41 orang guru di MTsN 2 Kota Palangka Raya terdapat 1 orang (3\%) memiliki kompetensi profesional guru yang sangat kurang. 3 orang (7\%) memiliki kompetensi profesional guru yang kurang. 11 orang (27\%) memiliki kompetensi profesional guru yang cukup. 21 orang $(51 \%)$ memiliki kompetensi profesional guru yang baik. 5 orang $(12 \%)$

Untuk mengetahui nilai minat belajar siswa terdapat 19 butir pertanyaan yang disediakan dengan 5 alternatif jawaban. Berikut distribusi frekuensi variable minat belajar siswa :

Tabel 4. Distribusi Frekuensi Variabel Minat Belajar Siswa

\begin{tabular}{ccccc}
\hline \multirow{2}{*}{ No } & \multirow{2}{*}{ Interval Skor } & Kriteria & \multicolumn{2}{c}{ Frekuensi } \\
\cline { 3 - 5 } & & F & $\%$ \\
\hline $59-65$ & Sangat Kurang & 7 & $7 \%$ \\
\hline $66-72$ & Kurang & 27 & $27 \%$ \\
\hline $73-79$ & Cukup & 32 & $32 \%$ \\
\hline $80-86$ & Baik & 24 & $24 \%$ \\
\hline $87-94$ & Sangat Baik & 9 & $9 \%$ \\
\hline Jumlah & & 100 & $100 \%$ \\
\hline
\end{tabular}

Berdasarkan tabel di atas dapat diketahui dari 100 orang siswa di MTsN 2 Kota Palangka Raya terdapat 7 orang (7\%) yang memiliki minat belajar yang sangat kurang, 27 orang (27\%) memiliki minat belajar yang kurang, 32 orang (32\%) memiliki minat belajar yang cukup, 24 orang (24\%) memiliki minat belajar yang baik, dan 9 orang (9\%) memiliki minat belajar yang sangat baik.

Uji normalitas dimaksudkan untuk mengetahui apakah data variabel berdistribusi normal atau tidak. Pengujian normalitas ini menggunakan Kolmogorof Smirnov dengan bantuan komputer program SPSS 24 For Windows. Dengan ketentuan apabila nilai signifikansi dari hasil uji Kolmogorof Smirnov > 0,05 maka asumsi normalitas terpenuhi. Dari hasil uji normalitas diatas diperoleh nilai signifikan sebesar 0,712 untuk variabel kompetensi profesional guru dan nilai signifikan sebesar 0,703 untuk variabel minat belajar siswa. Nilai signifikan tersebut lebih besardari 0,05 sehingga asumsi normalitas terpenuhi. Hal ini berarti data berdistribusi normal. 
Hasil perhitungan uji validitas di bandingkan dengan angka kriteria tabel korelasi nilai $\mathrm{r}$ pada taraf signifikan 5\%. Masing - masing pertanyaan dianggap valid apabila skor tiap butir pertanyaan lebih besar dari angka $r$ tabel. Dengan $n=30$ pada taraf signifikansi $5 \%$ angka $r$ tabelnya adalah 0,34. Setelah data dihitung dengan bantuan SPSS 24 For Windows, maka hasil dari perhitungan tersebut tidak ada yang dinyatakan gugur atau tidak valid. Nilai pada setiap item variabel kompetensi profesional guru dapan dilihat pada lampiran 2 dan nilai variabel minat belajar pada lampiran 4. Dari hasil perhitungan koesioner uji coba yang berisi 19 pertanyaan untuk variabel kompetensi profesional guru yang dihitung dengan bantuan SPSS 24 For Windows, diketahui bahwa data yang diperoleh dari kuesioner uji coba variabel kompetensi profesional guru adalah reliabel dengan nilai $r=0,746$ sehingga dinyatakan reliabilitas "Tinggi".

Dari hasil perhitungan koesioner uji coba yang berisi 19 pertanyaan untuk variabel minat belajar siswa yang dihitung dengan bantuan SPSS 24 For Windows, diketahui bahwa data yang diperoleh dari kuesioner uji coba variabel kompetensi profesional guru adalah reliabel dengan nilai $\mathrm{r}=0,651$ sehingga dinyatakan reliabilitas "Tinggi".

Uji linieritas dilakukankan untuk mengetahui apakah variabel bebas memiliki lineritas terhadap variabel terikat. Pengujian ini dilakukan dengan menggunakan Test For Linearity pada taraf signifikan 0,05. Kedua variabel dikatakan mempunyai hubungan linier apabila nilai signifikansi >0,05. Uji linieritas dilakuakn dengan bantuan komputer program SPSS 24 For Windows. Dari tabel hasil uji linieritas diatas diketahui nilai signifikan 0,326 $>0,05$. Maka dapat disimpulkan bahwa terdapat hubungan yang liniera antara variabel kompetensi profesional guru dan minat belajar siswa.

Dalam penelitian ini analisis regresi linier sederhana digunakan untuk menguji hipotesis dan menganalisis pengaruh kompetensi profesional guru terhadap minat belajar siswa di MTsN 2 Kota Palangka Raya. Perhitungan analisis regresi linier sederhana dilakukan dengan bantuan SPSS 24 For Windows. Adapun hasilnya adalah sebagai berikut : Dari hasil pengujian diatas diketahui nilai constant (a) sebesar 7,665 dan nilai koefisien regresi (b) sebesar 0,285. Konstanta sebesar 7,665 mengandung arti bahwa nilai konsisten variabel minat belajar adalah 7,665. Dengan kata lain, minat belajar siswa di MTsN 2 Kota Palangka Raya sebelum atau tanpa adanya variabel bebas ( kompetensi profesional guru ) adalah sebesar 7,665\%.

Dari persamaan diatas diketahui nilai regresi variabel $\mathrm{X}$ sebesar 0,285 yang berarti bahwa setiap penambahan 1 nilai kompetensi profesional guru, maka nilai minat belajar siswa bertambah sebesar 0,285. Koefisien regresi tersebut bernilai positif, sehingga dapat dikatakan bahwa arah pengaruh variabel $\mathrm{X}$ terhadap variabel $\mathrm{Y}$ adalah positif atau dengan katalain terdpat pengaruh kompetensi profesional guru terhadap minat belajar siswa.mUntuk mengetahui tingkat signifikansi pengaruh kompetensi profesional guru terhadap minat belajar siswa dapat dilihat dengan membandingkan nilai signifikansi dengan nilai probabilitas 0,05. Pada tabel 69 diketahui nilai signifikan $0,003<0,05$. Karena nilai signifikan lebih kecil dari nilai probabilitas 0,05 maka dari itu dapat diartikan bahwa terdapat pengaruh yang signifikan kompetensi profesional guru terhadap minat belajar siswa di MTsN 2 Kota Palangka Raya.

Selanjutnya untuk mengetahui seberapa besar pengaruh kompetensi profesional guru terhadap minat belajar, maka dilakuakan alanalisis koefisien determinasi $\mathrm{R}$ Square $\left(\mathrm{R}^{2}\right)$. Hasil analisis yang diperoleh akan dibandingkan dengan kriteria koefisien. Dari hasil didapatkan besarnya $\mathrm{R}^{2}$ adalah 0,588 . Artinya adalah pengaruh kompetensi profesional guru terhadap minat belajar siswa sebesar 58,8\% dengan kategori sedang. Sedangkan sisanya 41,2\% dipengaruhi oleh variabel - variabel lain diluar model regresi dalam penelitian ini. Berdasarkan hasil analisis tersebut, dapat disimpulkan bahwa hipotesis yang diajukan yaitu terdapat pengaruh antara kompetensi profesional guru terhadap minat belajar siswa di terima. 


\section{KESIMPULAN}

Berdasarkan analisis data diperoleh persamaan regresi liniermY $=7,665+0,285 \mathrm{X}$. Dari persamaan tersebut diketahui nilai regresi variabel $X$ sebesar 0,285 yang berarti bahwa setiap penambahan 1 nilai kompetensi profesional guru, maka nilai minat belajar siswa bertambah sebesar 0,285 . Koefisien regresi tersebut bernilai positif, sehingga dapat dikatakan bahwa arah pengaruh variabel $\mathrm{X}$ terhadap variabel $\mathrm{Y}$ adalah positif atau dengan katalain terdpat pengaruh kompetensi profesional guru terhadap minat belajar siswa.

Tingkat signifikansi pengaruh kompetensi profesional guru terhadap minat belajar siswa dapat dilihat dari nilai signifikan $0,003<0,05$. Karenanilai signifikan lebih kecil dari nilai probabilitas 0,05 maka dari itu dapat diartikan bahwa terdapat pengaruh yang signifikan kompetensi profesional guru terhadap minat belajar siswa di MTsN 2 Kota Palangka Raya.Berdasarkan hasil perhitungan koefisien determinasi $\mathrm{R}$ Square $\left(\mathrm{R}^{2}\right)$ diperoleh nilai $\mathrm{R}^{2}=0,588$. Artinya adalah pengaruh kompetensi profesional guru terhadap minat belajar siswa sebesar 58,8\% dengan kategori sedang. Sedangkan sisanya 41,2\% dipengaruhi oleh variabel - variabel lain diluar model regresi dalam penelitian ini.

\section{DAFTAR PUSTAKA}

Abdul, Amka. 2012. Guru Profesional Berkarakter. Klaten: Cempaka Putih

Ahmadi, Abu. 2012. Metodelogi Penelitian. Jakarta: Bumi Aksara.

Amirin, Tatang M. 2011. ManajemenPendidikan. Yogyakarta:UNY Press

Arikunto, Suharsimi. 2006. Prosedur Penelitian. Jakarta: Rineka Cipta.

Aziz, Hamka Abdul. 2012. Karakter Guru Profesional Melahirkan Murid unggul Menjawab Tantangan Masa Depan. Jakarta: Al - Mawardi Prima

Bungin, Burhan. 2009. Metodologi Penelitian Kuantitatif. Jakarta: Kencana Prenada Media.

Dalyono, M. 2015. Psikologi Pendidikan. Jakarta: Rineka Cipta

Daryanto. 2006. Administrasi Pendidikan. Jakarta: Rineka Cipta

Djamarah, Syaiful Bahri. 2010. Guru \& Anak Didik Dalam Interaksi Edukatif. Jakarta: Rineka Cipta.

Ghozali. 2006. Penelitian Kuantitatif. Jakarta: Rineka Cipta.

Hamalik, Oemar. 2010. Proses Belajar Mengajar. Jakarta: Bumi Aksara

Kunandar. 2009. Guru Profesional Implementasi Kurikulum Tingkat Satuan Pendidikan (KTSP) dan sukses dalam seertifikasi guru. Jakarta: Rajawali Press.

Kunandar. 2013. Guru Profesional Implementasi Kurikulum Tingkat Satuan Pendidikan (KTSP) dan sukses dalam seertifikasi guru ( Edisi revisi ). Jakarta: Rajawali Press.

Musafa, Jejen. 2011. Peningkatan Kompetensi Guru. Jakarta: Kencana Prenada Media Group.

Nurdin, Muhamad. 2004. Kiat Menjadi Guru Profesional. Yokyakarta: Prisma Shopie.

Rusdiana, H.A \& Yeti Heryati. (2015). Pendidikan Profesi Keguruan : Menjadi Guru Inspiratif dan Inovatif. Bandung: Pustaka Setia

Rusman. 2014. Model - Model Pembelajaran. Jakarta: PT Raja Grafindo Persada.

Sagala, Syaiful. 2009. Kemampuan Profesional Guru dan Tenaga Kependidikan. Bandung: Alfabeta.

Sardiman, A.M. 2007. Interaksi dan Motivasi Belajar dan Mengajar. Jakarta: Grasindo.

Slameto. 2010. Belajar dan Faktor - Faktor yang Mempengaruhinya. Jakarta: Rineka Cipta.

Soemanto, Wasty. 2012. Psikologi Pendidikan : Landasan Kerja Pemimpin Pendidikan. Jakarta: Rineka Cipta.

Subana. 2005. StatistikPendidikan. Bandung: Pustaka Setia.

Susanto, Ahmad. 2013. Toeri Belajar \& Pembelajaran. Jakarta: Kencana Perdana Media Gorup.

Sugiyono. 2011. Metode Penelitian Kuantitatif, dan R\&D. Bandung: Alfabeta.

Syah, Muhibbin. 2010. Psikologi Pendidikan. Bandung: PT Remaja Rodakarya. 
Syah, Muhbbin. 2013. Psikologi Belajar. Jakarta: PT Raja Grafindo Persada.

Usman, M. Uzer. 2005. Menjadi Guru Profesional. Bandung: Remaja Rosda Karya.

Yahya, Murip. 2013. Profesi Tenaga Kependidikan. Bandung: Pustaka Setia.

Manahen Hania. 2010. Pengaruh Profesionalitas Guru Terhadap Motivasi Belajar Siswa SMP Trakanta Solo Baru Grogol Sukoharjo. Diakses tanggal 24 januari 2019 dari https://repository.usd.ac.id/22717/2/061124030_Full.pdf

Rohman, Binti Afidatur. 2017. Pengaruh Kompetensi Profesional Guru Terhadap Motivasi Belajar Siswa Madrasah Ibtidaiyah (MI) Raden Patah Pujon Malang. Diakses tanggal 24 januari 2019 dari http://etheses.uin-malang.ac.id/9608/1/12140134.pdf

Warman, Budi. 2015. Pengaruh Kompetensi Profesional Guru dan Motivasi Terhadap Hasil Belajar Siswa di Sekolah Menengah Kejuruan Negeri 1 Kota Jambi . Diakses tanggal 24 Januari 2018 dari http://repository.ut.ac.id/6818/1/42582.pdf 